\title{
RISK FACTOR ASSESSMENT FOR ACNE VULGARIS IN HUMAN AND IMPLICATIONS FOR PUBLIC HEALTH INTERVENTIONS IN NORTH CENTRAL INDIA: A SURVEY-BASED STUDY
}

\author{
AFIFA QIDWAI, MANISHA PANDEY, SHASHI KANT SHUKLA, ANAND PANDEY, RAJESH KUMAR, ANUPAM DIKSHIT* \\ Department of Botany, Biological Product Laboratory, University of Allahabad, Allahabad, Uttar Pradesh, India. \\ Email: anupambplau@rediffmail.com
}

Received: 23 January 2016, Revised and Accepted: 02 March 2017

\section{ABSTRACT}

Objective: The aim of the present study is to deal with the population based field study regarding factors that might play essential role in occurrence or epidemiology of Acne vulgaris in north central India.

Methods: This cross-sectional study was a population based field study. Populations were assessed for influence of various factors on acne prevalence. The study was carried out from April 2016 to October 2016 in north central India. For this survey, questionnaires were designed to cover all the required information regarding the incidence of acne that includes factors such as gender, age, skin type, complexion, season of the incidence, and dietary habit.

Results: Acne vulgaris appears to be influenced by gender, age, seasonal variations, breakout area, complexion, skin types, and dietary habits. Further, the influence of dietary habit on acne, particularly the consumption of dairy products or high-carbon diet has also been evaluated. Apart from depicting the vulnerable range of age $(\mathrm{p}=0.003288)$, sensitivity on various skin types $(P=0.00039)$ and complexion $(P=0.001355)$ on the basis of gender; this field study on acne vulgaris, also reveals that the season has inordinate role in acne pervasiveness $(P=0.115731)$.

Conclusion: This study is helpful in categorizing the risk factors and manifesting the afflictions of acne in population thus, contributing health-care planning.

Keywords: Acne, Prevalence, Risk factors, Post management.

(C) 2017 The Authors. Published by Innovare Academic Sciences Pvt Ltd. This is an open access article under the CC BY license (http://creativecommons. org/licenses/by/4. 0/) DOI: http://dx.doi.org/10.22159/ajpcr.2017.v10i5.17265

\section{INTRODUCTION}

Various superficial infectious agents are responsible for human skin problems. In this row, acne vulgaris is one of the most common chronic diseases of the pilosebaceous unit. It affects almost $85 \%$ of adolescents when they undergo maximum physical, psychological, and social changes [1]. This problem is neither life-threatening nor physically incapacitating, but generally procures the image of face. Moreover, it can affect the metabolic functioning and erode self-esteem of susceptible individuals [2]. Moving toward the factors influencing acne, female patients tend to develop acne earlier with high persistency than males whereas male suffers with the severe form of acne vulgaris [3-8]. Therefore, it is the demanding need of the present scenario to focus on the wide range of an epidemiological survey on acne vulgaris. Population-based data of epidemiologic survey are significant in computing tools to identify the risk factors, treatments, and expenses of health services. However, community sampling records are considered as an effective method of dermatological investigations of acne cases, in spite of this, it is rare [9].

The aim of the present study is to reveal the multifactorial prevalence of acne vulgaris and various demographic features along with its probable factors that affect the frequency to some extent. To the best of our knowledge, no similar studies have been reported from the north central part of India till date.

\section{METHODS}

This cross-sectional study was a population-based field study intending to discern the factors that influence the prevalence of acne in adolescents. The study carried out from April 2016 to October 2016 in the north central part of India. For this survey, questionnaires were designed to cover all the required information regarding the occurrence of acne that includes factors such as gender, age, skin type, complexion, season of the occurrence, dietary habit etc [10]

The schools, colleges, universities as well as local residential colonies including slum areas were taken under consideration. We seek permission for the survey from principals of all the selected institutions. The assortments of the area were made in such a way so as to represent all the socioeconomic groups. We demonstrated the candidates in school, colleges, and in communities the required information about acne and about the survey by lectures and presentations and administer the questionnaires. This study was approved by the hospital research.

Grading of questionnaire responses

The grading of questionnaire was designed as such so that all the possible factors influencing the acne prevalence were considered. The different socioeconomic groups were included to conclude the effect of sanitation, dietary habit, candidates that approach different medical help and to share candidate's personal household remedies experience that can help in further studies. The major factors were as follows:

\section{Gender and age}

The gender-based analyses were done by grouping male and female individuals. This is an important factor as there are considerable variations in the prevalence due to variations in hormones. On the basis of gender, most of the other factors were evaluated. To address both the gender equality, we seek coeducation and segregated institutes. Candidates were asked to assess their age, divided into groups (6-12, 12-18, 18-24, 24-30, and 30-36) and their gender, i.e., male or female as well as to evaluate the severity of their acne infection. 


\section{Severity}

Candidates were classified according to their infection in the three following categories: Mild, moderate, and severe. We pre-demonstrated the candidates how to examine their infection severity. They were asked to mention their severity infection frequency on an average has been of great concern in the epidemiologic analysis.

\section{Seasonal variations}

Seasonal variations in disease frequency have been of great interest in the epidemiologic investigation, the seasonality of disease and mortality has been observed for centuries. Therefore, the effects of climatic changes (humidity, sunlight, cold, and temperature) on the skin were also aimed to be assessed in the questionnaires with the heads of summer, winter, autumn, spring, and all seasons. Since the candidates have variable sensitivity to the varying seasons; we seek to investigate the seasons, in which the individual candidate has suffered the most.

\section{Complexion}

The complexions were assessed as fair, moderate, and dark. Although the effects of complexion are hardly reported yet, we have taken it under consideration, which proves worthy.

\section{Skin type}

It was mentioned under following heads, i.e., oily, dry, normal, and complex. The skin types play a noteworthy role to influence acne frequency and severity. As the oily content (sebum) promotes anaerobic bacteria growth

\section{Marital status}

We have taken this factor as married or unmarried, but it is found to have no association with acne severity.

\section{Breakout area}

To mention their area of the breakout, the candidates were provided with four responses, i.e., face, back, chest, and forehead.

\section{Dietary habits}

To study the relationship between the dietary habit and frequency of acne disease. The dietary habit were assessed using weekly food diary, including high glycemic diet, dairy products, fatty, spicy diet, and chocolate consumption. The frequency of consumption of dairy products was taken as regulated (organized) factors, and the grade of severity of acne disease or its absence was taken as efficacious characteristic. The dietary habit was assessed under the heads of high glycemic diet, dairy products, spicy food (junk food) fatty food, and chocolate. The quantity and quality of glycemic index (GI) defined by glycemic load (GL). The GL was calculated from the weekly food diaries by given formula.

$\mathrm{GL}=\mathrm{GI}$ for food items $\times$ its carbohydrates in grams $(\mathrm{g} / 100)$

Moreover, the GI values were taken from the international table of GI [11] the GI was estimated using similar food of known GI.

\section{Household remedies}

For assembling individual's personal experience or their knowledge of acne curatives, we had set a separate column for the household remedies.

\section{Study areas}

Areas were selected by simple random method taking into account to represent all the socioeconomic and age groups. These are schools, universities, and local residential areas including the slum area so as to include different ethnic groups and cultural practices and hygiene.

\section{Subject selections}

Totally, 1500 subjects were under assessment from the different areas out of which, 648 were male, and 852 were female within the age range of 6 year old to 36 years. Questionnaires were distributed to all the candidates and verbally interpreted in simple language or folk language so as to avoid any kind of misunderstanding and to enable accurate response by the participants.

\section{Statistical analysis}

Further, data were collected based on the frequencies of occurrence and statically analyzed with a Pearson's Chi-square test to assign significant differences between the groups where the significance level was set at $P<0.05$. The odds ratio was calculated in adjusted logistic regression models.

\section{RESULTS}

The 1500 respondents were surveyed in between the age range of 6-36 years. Total 39\% respondents were found affected, with $41.6 \%$ male candidates out of whom $29.6 \%$ were cases whereas $58.3 \%$ were female with $45.7 \%$ cases. The results clearly reflected that females were more affected than males (Table 1 and Fig. 1b).

Our observation reveals the prevalence of acne which is directly proportional to the age of 14-24/25 (Table 1 and Fig. 1a). However, acne occurrence is indirectly proportional to the age above than 25 . There, we observed the rare cases of acne in the age of 6-12 years of female candidates although percentage is very low $(0.13 \%)$. Although in each group of age, females have higher prevalence than males. The age variations are statistically significant $(P=0.00329)$ (Table 1$)$.

Coming to the next parameter, the skin type was proved to be another effective factor. It was under the heads of oily, dry, normal, and complex skin type. Oily skin showed higher sensitivity toward the infection $42.9 \%$ in female and $17 \%$ in male out of total, i.e., $60.3 \%$ (Fig.2). Dry skins are also prone to infection but comparatively lesser percentage is reported, i.e., $20.8 \%$ in female and $14.01 \%$ in male from $34.8 \%$ as a total (Fig. 1b). Whereas, normal and complex skin types have negligible sensitivity which is highly significant $(P=0.00039)$ (Table 1 and Fig. 1c).

Further, the impact of complexion on acne prevalence is also noteworthy. Moderate is more at risk than the fair and dark complexions $(68.3 \%, 24 \%$, and $17 \%$, respectively) which is also proved by p value, i.e., 0.00135 (Table 1 and Fig. 1d). However, seasonal variation is reported as one of the most valuable factors, in which summers (61.3\%) are most infectious (Fig. 1e and 2a-i severe

Table 1: Acne prevalence among the genders, based on various factors

\begin{tabular}{lllll}
\hline Factor & Range & Male & Female & P=0.05 \\
\hline Age & $6-12$ & 0 & 2 & 0.00329 \\
& $12-18$ & 43 & 79 & \\
& $18-24$ & 72 & 124 & \\
Skin type & $24-30$ & 60 & 130 & \\
& $30-36$ & 10 & 65 & 0.00039 \\
& Oily & 102 & 251 & \\
Face complexion & Dry & 82 & 122 & \\
& Normal & 0 & 5 & 0.00135 \\
& Complex & 1 & 22 & \\
Season & Mair & 33 & 50 & 0.03531 \\
& Moderate & 120 & 280 & \\
& Dark & 30 & 70 & \\
& Summer & 100 & 259 & \\
& Winter & 6 & 10 & \\
& Monsoon & 15 & 20 & \\
& Autumn & 17 & 18 & \\
& All & 47 & 93 & \\
\hline
\end{tabular}




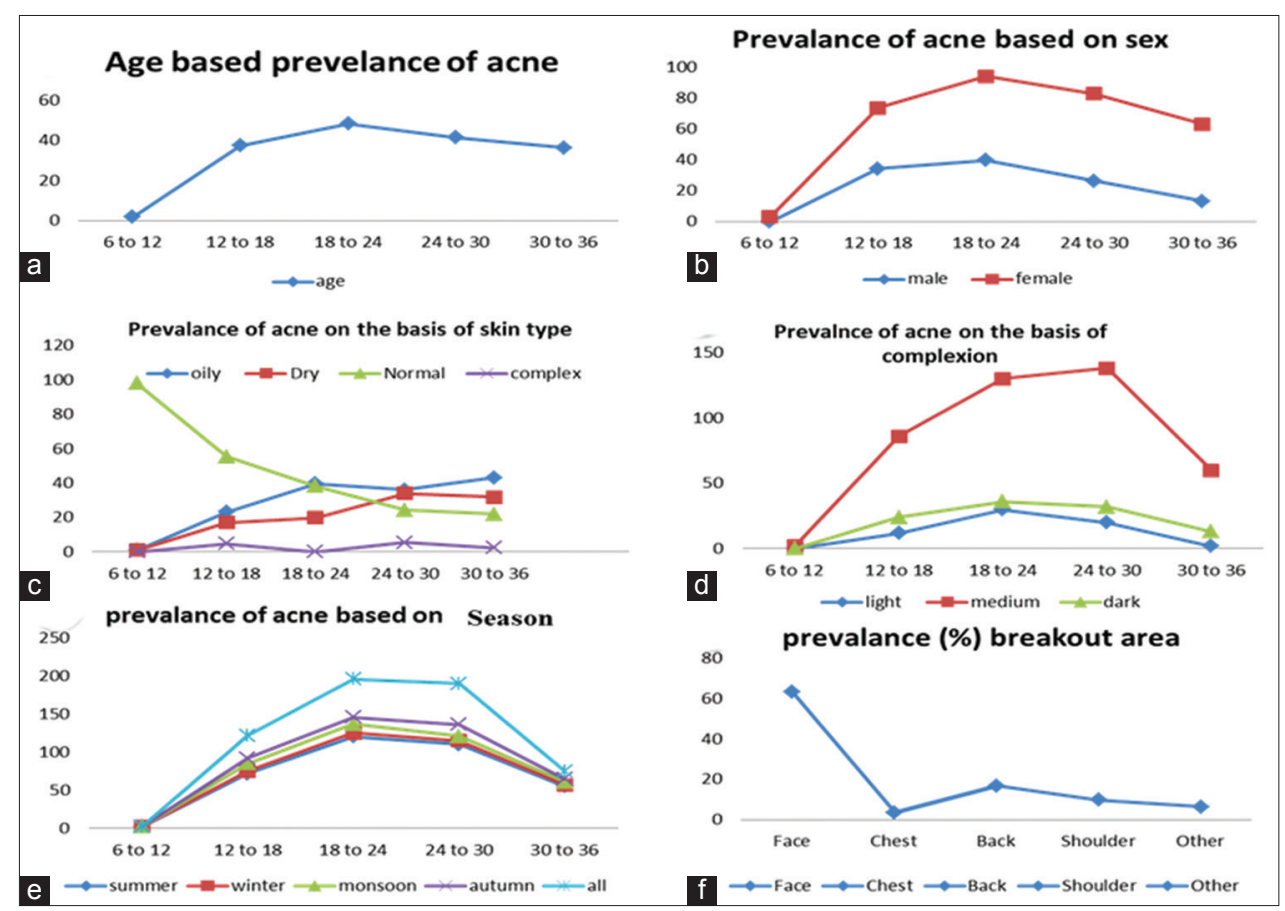

Fig. 1: Prevalence of acne: (a) Based on age, (b) based on sex, (c) based on skin type, (d) based on breakout area, (e) based on seasonal variation, (f) based on complexion
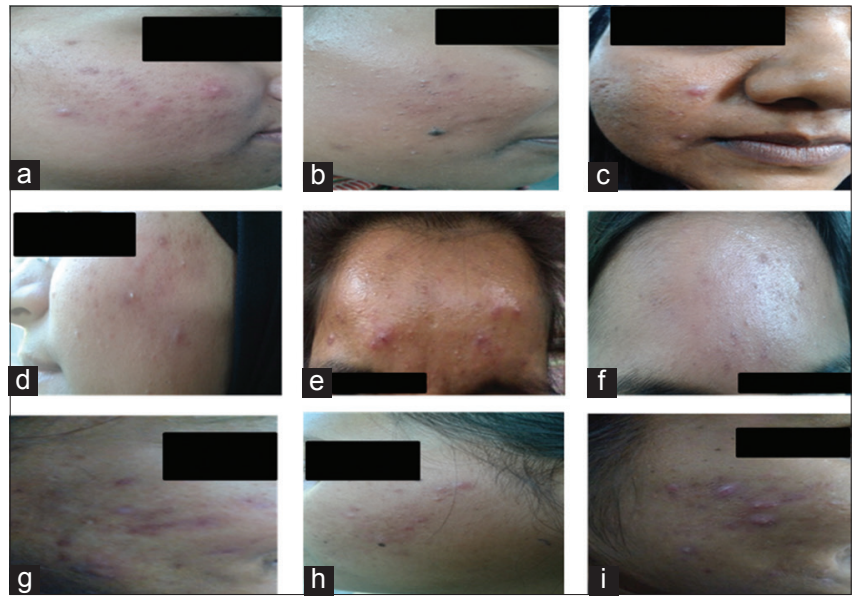

Fig. 2: (a-i) Images representing severity of acne persiveness during summer season on the face of moderate complexion and oily skin type

condition in summer) while other seasons, i.e., monsoon, autumn, and winter are less susceptible, respectively. The seasonal variation has significance of $P=0.035$ (Table 1). The face considers a having highest breakout area (Figs. 1f and 2a-i).

The marital status has found to be insignificant in acne perseverance. Regarding dietary habit, it was established from the data that consumption of high glycemic index diet and high glycemic load (GL) exacerbates risk of acne occurrence. Respondents with high GL daily dietary habits (i.e., consumption of $100 \mathrm{~g}$ of carbohydrates daily), make up $56.8 \%$ of total infected respondent, while consumptions with 2-3 times a week (i.e., consumption of $100 \mathrm{~g}$ of carbohydrates only 2-3 times/days/week) show $43.2 \%$, and there are no reports on rare consumption of carbohydrates. It is clear from the data that high GI diet computing high GL reflects its influence on promotion of acne. However, the consumption of dairy products and milk shows the risk of acne prevalence significantly higher among the respondent with daily consumption (52.6\%) than 2-3 times a week (29.3\%) and weekly (18.1\%). Data reveal a direct correlation between the dairy product consumption and risk of occurrence of acne [12] although the examinees consuming fatty and spicy foods show comparatively lowrisk competent than dairy products. Apart from this, consumption of chocolate reveals contrary effects (Fig. 3) [13,14].

Further interrogations during the survey, the personal experience of household remedies from respondent were assembled. Among the infected examinees, $64.8 \%$ seek household treatments, and $27.1 \%$ seek medical care, which may include allopathic, homeopathic, Ayurvedic, and Unani disciplinary. Moreover, 8.1\% respondents seek no treatments. All the information regarding household natural remedies were assessed and considered for the future prospects that may prove assistive for our study. Some of the information is listed in Table 2.

\section{DISCUSSION}

An individual can suffer from acne more easily and frequently than any other disease [4]. Our community-based study reveals that acne is commonly occurring problem in the age of puberty and shows extensive emotional impact and ultimately declines one's self-esteem. The present investigation shows the prevalence of acne in population, i.e., $39 \%$. There are many similar studies which have been reported globally till date such as in Turkey [25], Syria [26], Ankober Ethiopia [27], Northern Ethiopia [28], Taiwan [29], Australia [8], South India [3,30], Saudi Arab [31], Iran [1], Portugal [32], Malaysia [4], Greece [33], Brazil [34], Glasgow [35], Mexico [36], France [11] etc., (Table 3 and Fig. 4).

The present findings demonstrate similarities with the reports of Bogino et al. (2014) in Northern Ethiopia (19.4\%) [28], Perkins et al. (2012) in Taiwan (4.7\%) [29], Stathakis et al. (1997) [46] and Killkenny et al. (1998) [8] in Australia (10\%) and 36.1\%, respectively. Moreover, other global findings like that of Al-Ameer and Al-Akloby (2002) in Saudi Arabia 19.6\% [31], France 7.2\% (1996) [11], Mexico 2.5\% (1972) [36], Brazil 2.7\% (2014) [34], and Singapore 3\% (2007) [41] of community-based survey shows $11.2 \%$ and $19.6 \%$ of prevalence. The present findings show $39 \%$ of prevalence in north central India $[46,47]$.

However, our investigation shows lower number of cases than various other studies $91.3 \%$ [33], 86\% [2], 64\% [43] of occurrence suggest that 
Table 2: Some of the most frequently used household remedies

\begin{tabular}{|c|c|c|}
\hline Constituents & Procedure & Effects \\
\hline C. arietinum, C. longa, milk & $\begin{array}{l}\text { Cicer powder, curcuma longa in 3:1 ratio blend } \\
\text { with milk, applies paste } 10-15 \text { minutes }\end{array}$ & Reduce blemish, balance facial oil, clear pore [15] \\
\hline C. verum, honey & $1: 3$ ratio $C$. verum, honey apply $10-15$ minutes & It combat bacterial growth improves outbreak [17] \\
\hline O. sanctum & Finely crushed leaves applied for 15-20 minutes & Antibacterial, reduce blemish, balance oil [19] \\
\hline Azardirachta indica & Finely crushed leaves applied for $15-20 \mathrm{~min}$ & Antibacterial, antioxidant [16] \\
\hline C. papaya & Paste of papaya applies for 15-20 minutes & Reduce acne and scar, promotes growth of new healthy cells [20] \\
\hline Musa spp. & $\begin{array}{l}\text { Banana peel directly rubs in circular motion, for } \\
30 \text { minutes }\end{array}$ & Anti-inflammatory, reduce redness, and swelling [22] \\
\hline A. vera & Apply aloe gel directly on face & Antiseptic, oil balance [23] \\
\hline Mentha spp. & Crushed leaves juice, apply for 5-10 minutes & Exfoliate skin, astringent activity, reduce blemish [21] \\
\hline S. tuberosum & Potato juice, rub for few minute & Antioxidant, reduce blemish [18] \\
\hline A. sativum & $\begin{array}{l}\text { Garlic extract and water in 1:1 ratio for } \\
2-3 \text { minutes }\end{array}$ & Strong antibacterial, maintain circulatory and digestive system [24] \\
\hline
\end{tabular}

Table 3: Prevalence of acne vulgaris in adolescent age; global review

\begin{tabular}{|c|c|c|c|}
\hline Country & Study population & Prevalence $(\%)$ & Reference \\
\hline Mexico & 10,000 & 2.5 & Maldonado et al., 1977 [36] \\
\hline Glasgow & 2014 & 72 & Rademaker et al.,1989 [35] \\
\hline France & 923 & 7.2 & Daniel et al., 1996 [11] \\
\hline Peru & 1857 & 44.1 & Freyre et al., 1998 [12] \\
\hline Australia & 666 & 83.1 & Killkenny et al., 1998 [8] \\
\hline Turkey & 2652 & 23.1 & Atkan et al., 2000 [25] \\
\hline U K & 317 & 49.8 & Smithard et al., 2001 [37] \\
\hline Hong Kong & 522 & 91.3 & Yeung et al., 2002 [38] \\
\hline New Zealand & 9570 & 67.3 & Purvis et al., 2004 [39] \\
\hline Portugal & 1290 & 82.1 & Amado et al., 2006 [32] \\
\hline Singapore & 1045 & 87.9 & Tan et al., 2007 [41] \\
\hline Belgium & 594 & 94.9 & Nijsten et al., 2007 [42] \\
\hline Turkey & 563 & 64 & Uslu et al., 2007 [43] \\
\hline South India & 28917 & 1.068 & Adityan et al., 2009 [3] \\
\hline Iran & 1002 & 93.2 & Ghodsi et al., 2009 [1] \\
\hline Malaysia & 409 & 67.5 & Hanisah et al., 2009 [4] \\
\hline Taiwan & - & 4.7 & Perkins et al., 2012 [29] \\
\hline Greece & 1531 & 51.2 & Tasoula et al., 2012 [33] \\
\hline Ankober Ethiopia & - & 7.7 & Doni et al., 2013 [27] \\
\hline South India & 623 & 53.2 & $\begin{array}{l}\text { Samanthula et al., } \\
2013 \text { [30] }\end{array}$ \\
\hline Northern Ethiopia & 402 & 19.4 & Bogino et al., 2014 [28] \\
\hline Syria & - & 34.7 & Waqar et al., 2014 [26] \\
\hline Brazil & 52 & 96 & Bagatin et al., 2014 [31] \\
\hline Northern India & 1500 & 39 & This study \\
\hline
\end{tabular}

the selected region is lesser prone to acne. Although, it is reflected by community-based studies that Australia has the least prevalence of acne than Asians [48].

This study clearly reveals in the form of graphs, and tables which depicts prevalence frequency of acne is directly proportional to the age, from 20-36 (Fig. 1a), supported by the findings of Aktan et al. [25], Hanisah et al. [4] and Rademaker et al. [35] Moreover, females are more infected (45.7\%) than the males (29.6\%) (Fig. 1b and Table 1) which was also reported by Tallab [49] and Al-Ameer [31]. It might be due to hormonal changes, which are supposed to facilitate the initiation of premenstrual acne [50]. It is interesting that the season has an inordinate role in the initiation of acne (Fig. 1c). Summer and monsoon are found highly accountable. However, maximum cases are reported from summer season than monsoon, winter, and autumn (Table 1 and Fig. 1e) [31]. Further, seasonal variations regarding severity in acne pathogenesis are also considerable. This finding is contradicted with the traditional believes that acne improves in summer and aggravate in winter [51]. Probably, because low temperature and humidity adversely affect the epidermal stratum, that ultimately reduces the hydration level of corneum stratum. Hence, reduces the extensibility and resistance to fissuring [52].

On the other hand, sunlight intensity in the noon of midsummer is 130 times more than midwinter [53], and it was thought that UV rays are beneficial to acne. Therefore, sun-bath sustains the restoration of inflammatory lesions by increasing blood circulation [54,55]. Apart from all, the study regarding seasonal variation, result of our study is against the conventional beliefs, supported by Indian survey reports that acne intensifies during summer (Fig. 1e and Table 1) [3,4].

The pilosebaceous unit rich areas are most susceptible site of acne vulgaris, i.e., face (Fig. 1f and Table 1). In the present study, face is reported by $100 \%$ of cases, validating face as a core playground of acne 


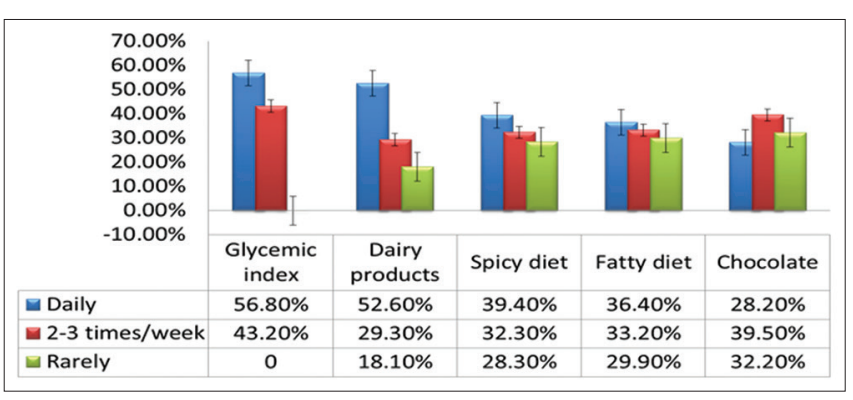

Fig. 3: Graphical illustration of effect of dietary habit on prevalence of Acne vulgaris

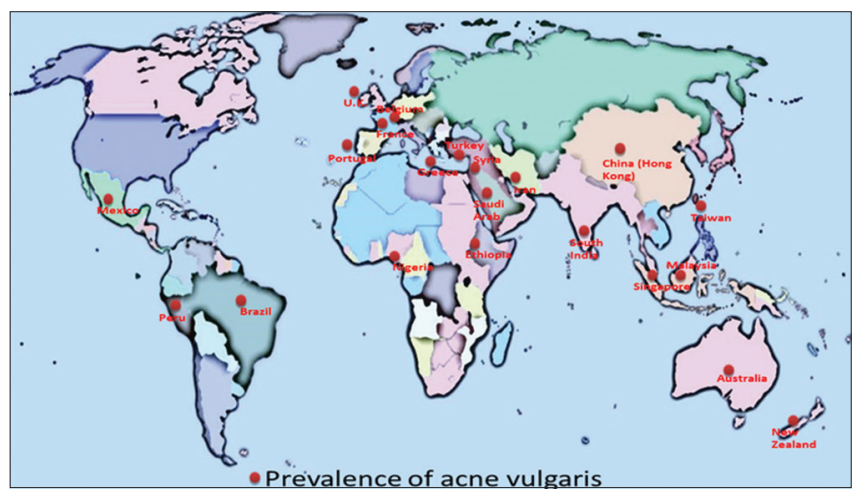

Fig. 4: Acne vulgaris: A global representation of occurrence

vulgaris. Further, back reported to be $30 \%$, chest with $18 \%$, shoulder with $6 \%$, and others with $10 \%$ (Fig. 2f) [3,5,32]. Since each skin has varied level of sensitivity based on its type. Therefore, another notable factor in this study is skin type. Medium complexion and oily skin (68.3\% and $60.3 \%$ respectively, among the entire acne patient) are more likely to be predisposed to skin damage from the sun (Fig. 2) than light and dark complexion. Dry skin is the next leading skin condition prone to acne (34.8\%) shown by our investigation (Fig. 2c and f).

The high glycemic diet shows adequate impact on acne prevalence [56]. Diets with a high GI, such as white bread, sugar, popcorn, and white rice, are promptly absorbed, conducting increased blood glucose levels and corresponding higher levels of insulin and insulin-like growth factor-1 [57]. It has been shown to enhance sebum production, stimulate adrenal androgen synthesis, and increase androgen bioavailability and facilitating cell proliferation, all of which play a role in the pathogenesis of acne [57], it is the GL that is deciding factor for acne prevalence. GL takes into account the quantity of carbohydrates consumed as well as the rate of carbohydrate absorption. Further, it is also reported that low GL diet resulted in improvement of acne, with improvement in insulin sensitivity, a decrease in testosterone bioavailability, and a reduction in adrenal androgens (Fig. 3) [58].

In addition, dairy diets reveal to comprise positive impacts; proposed justification for this relationship includes revelation of androgen precursors, anabolic steroids [59], and other biogenic elements, namely, whey protein, di-hydro testosterone precursors, and insulin-like growth factor-1 increase [60]. Endocrine factor involved in acne pathogenesis may be affected by dairy product consumption because milk is an insulinotropic nutrient with high-insulin emic index. Like GI, dairy products also increase blood insulin level and IGF-1 [60]. Chocolate consumption has validate negative impact on acne prevalence, possibly it may amends the severity as studies have reported high antioxidant activity of cocoa and presence of phenolic phytochemicals may exhibit remedial benefits to skin [61,62]. Supplementary, spicy, and fatty dietary habit has comparatively increased impact on the occurrence of acne $[63,64]$. These determinations might have influenced by the lack of diagnostic inaccuracy and recall preconceptions.
The knowledge we gain from the participants were given the equal evaluating worth as they can prove assistive for our research work. These informations are summarized in Table 2.

\section{CONCLUSION}

Our study has profiled out various possible factors accountable for acne prevalence. This population-based study in North central zone of India shows lower occurrence than other Asian countries and Africa. The prevalence is higher in females of this zone. Our survey intensifies the fact that season and dietary habit does effects acne. Facial acne is common among patients that cause foremost impression on their quality of life. Assessment of quality of life in patients with acne is needed as it helps in the pharmacological as well as psychological treatment of the patients in a more active and assimilated way.

\section{REFERENCES}

1. Ghodsi SZ, Orawa H, Zouboulis CC. Prevalence, severity, and severity risk factors of acne in high school pupils: A community-based study. J Invest Dermatol 2009;129(9):2136-41. Available from: https://www. ncbi.nlm.nih.gov/pubmed/19282841.

2. Balkrishnan R, Kulkarni AS, Cayce K, Feldman SR. Predictors of healthcare outcomes and costs related to medication use in patients with acne in the United States. Cutis 2006;77(4):251-5. Available from: https://www.ncbi.nlm.nih.gov/pubmed/16706243.

3. Adityan B, Thappa DM. Profile of acne vulgaris - a hospital-based study from South India. Indian J Dermatol Venereol Leprol 2009; 75(3):272-8. Available from https://www. ncbi. nlm. nih. gov// pub med/ 19439880

4. Hanisah A, Omar K, Shah SA. Prevalence of acne and its impact on the quality of life in school-aged adolescents in Malaysia. J Prim Health Care 2009;1(1):20-5. Available from: https://www.ncbi.nlm.nih.gov/ pubmed/20690482.

5. Simpson NB, Cunliffe WJ. Disorders of sebaceous glands. In: Burns T, Breathnach S, Cox N, Griffiths C, editors. Rooks Textbook of Dermatology. $7^{\text {th }}$ ed. Oxford: Blackwell Publishing; 2004. p. 43.143.75.

6. Gelmetti CC, Krowchuk DP, Lucky AW. Acne. In: Schachner LA, Katz SI, editors. Pediatric Dermatology. $3^{\text {rd }}$ ed. Philadelphia: Mosby; 2003. p. 589-609.

7. Burton JL, Cunliffe WJ, Stafford I, Shuster S. The prevalence of acne vulgaris in adolescence. Br J Dermatol 1971;85(2):119-26. Avaibale from: https://www.ncbi.nlm.nih.gov/pubmed/4255129.

8. Killkenny M, Merlin K, Plunkett A, Marks R. The prevalence of common skin conditions in Australian school students: 3. acne vulgaris. Br J Dermatol 1998;139(5):840-5. Available from: https://www.ncbi. nlm.nih.gov/pubmed/9892951.

9. Zaenglein AL, Graber EM, Thiboutot DM, Strauss JS. Acne vulgaris and acneiform eruptions. Fitzpatricks Dermatology in General Medicine. $7^{\text {th }}$ ed. New York: McGraw Hill Publishing; 2008. p. 690-703.

10. Cheesbrough MD. District Laboratory Practice in Tropical Countries Part 2. UK: Cambridge University Press; 2000.

11. Foster-Powell K, Holt SH, Brand-Miller JC. International table of glycemic index and glycemic load values: 2002. Am J Clin Nutr 2002;76(1):5-56. Available from https://www.ncbi.nlm.nih.gov/ pubmed/12081815.

12. Daniel F, Dreno B, Poli F, Auffret N, Beylot C, Bodokh I, et al. Descriptive epidemiological study of acne on scholar pupils in France during autumn 1996. Ann Dermatol Venereol 2000;127(3):273-8. Available from: https:/www.europepmc.org/abstract/med/10804300

13. Freyre EA, Rebaza RM, Sami DA, Lozada CP. The prevalence of facial acne in Peruvian adolescents and its relation to their ethnicity. J Adolesc Health 1998;22(6):480-4. Available from: https://www.ncbi.nlm.nih. gov/pubmed/9627819.

14. Natalya T. The influence of dietary habits on acne. World J Med Sci 2013;8(3):212-6. Available from: https://www.idosi.org/wjms/8(3)13/8.pdf. Available from:

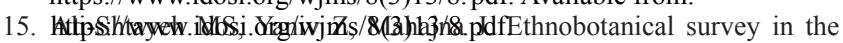
Palestinian area: A classification of the healing potential of medicinal plants. J Ethnopharmacol 2000;73(1-2):221-32.

16. Farhat SD, Shubhangi W, Mamta J, Pande G. Development of herbal anti acne gel and its evaluation against acne causing bacteria Propionibacteriam acnes and Staphylococcus epidermidis. Int J Res Ayurveda Pharm 2013;4(5):781-6. Available from: http://www.ijrap. net/admin/php/uploads/1111_pdf.pdf.

17. BalijepalliMK,BuruAS,SakirollaR,PichikaMR.Cinnamomumgenus: A review on its biological activities. 2016;9(2):1-11. Available from: 
http://www.innovareacademics.in/journals/index.php/ijpps/arti cle/view/11156/9561. Available from: https://http://innovareacademics.in/

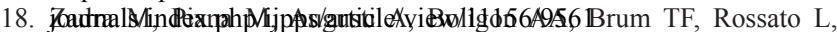
et al. In vitro evaluation of the antimicrobial and antimycobacterial activities of Solanum guaraniticum A. St.-Hil. Leaves. J Appl Pharm Sci 2013;3(9):19-23.

19. Viyoch J, Pisutthanan N, Faikreua A, Nupangta K, Wangtorpol K, Ngokkuen J. Evaluation of in vitro antimicrobial activity of Thai basil oils and their micro-emulsion formulas against Propionibacterium acnes. Int $\mathrm{J}$ Cosmet Sci 2006;28(2):125-33. Available from: onlinelibrary.wiley.com/doi/10.1111/j.1467-2494.2006.00308.

20. Akujobi CN, Ofodeme CN, Enweani CA. Determination of antibacterial activity of (paw- paw) extracts Carica papaya. Niger J Clin Pract 2010;13(1):55-7. Available from: http://www.ajol.info > Journal Home > Vol 13, No 1 (2010).

21. Qidwai A, Pandey M, Shukla SK, Kumar R, Pandey A, Dikshit A. Antibacterial activity of Mentha piperita and Citrus limetta against Propionibacterium acnes (Anaerobic bacteria). Int J Pharm Sci Res 2016;7(7):2917-24.

22. Okechukwu RI, Onyedineke NE, Mgbemena IC, Opara FN, Ukaoma AA. Inhibition of pathogenic microorganisms by ethnobotanical extracts of fruit peels of Musa paradisiaca. J Appl Pharm Sci 2012;2(4):1-3. Available from: http://www.japsonline.com/admin/php/uploads/418_ pdf.pdf.

23. Agaoglu S, Suleyman AJ. Investigation of in vitro antimicrobial activity of Aloe vera juice. J Anim Vet Adv 2009;8(I):99-102

24. Douaouya L, Bouzerna N. Effect of Garlic (Allium sativum L.) on biochemical parameters and histopathology of pancreas of Alloxaninduced diabetic rats. Int J Pharm Pharm Sci 2016;8. Available from: https://innovareacademics.in/journals/index.php/ijpps/article/ viewFile/11378/5134.

25. Aktan S, Ozmen E, Sanli B. Anxiety, depression, and nature of acne vulgaris in adolescents. Int J Dermatol 2000;39(5):354-7.

26. Waqar A, Nik NA, Sabzali M. Socio demographic characteristics of acne among university students in Damascus, Syria. Epidemiol Res Int 2014;10:4. Available from: https://www.hindawi.com/journals/ eri/2014/974019/abs/.

27. Doni SN, Murgia V, Beraldo M, Shibeshi D. A mobile community dermatologic clinic in Ankober Woreda, central Ethiopia. Community Dermatol J 2013;8:1-12

28. Bogino EA, Kebede MG, Kahsay AB. Acne at Ayder referral hospital among patients attending dermatologic clinic, Mekelle, Northern Ethiopia. Sci J Clin Med 2014;3:129-34. Available from: http://www. article.sciencepublishinggroup.com/.../10.11648.j.sjcm.20140306.16. pdf.

29. Perkins AC, Maglione J, Hillebrand GG, Miyamoto K, Kimball AB. Acne vulgaris in women: Prevalence across the life span. J Womens Health (Larchmt) 2012;21(2):223-30. Available from: https://www. ncbi.nlm.nih.gov/pubmed/22171979.

30. Samanthula H, Kodali M. Acne and quality of life-A study from a tertiary care centre in South India. IOSR J Dent Med Sci 2013;6(3):59-62. Available from: http:/www.iosrjournals.org/iosr-jdms/papers/Vol6issue3/O0965962.pdf.

31. Al-Ameer AM, Al-Akloby OM. Demographic features and seasonal variations in patients with acne vulgaris in Saudi Arabia: A hospital-based study. Int J Dermatol 2002;41(12):870-1. Available from: https://www.ncbi.nlm.nih.gov/pubmed/12492972.

32. Amado JM, Matos ME, Abreu AM, Loureiro L, Oliveira J, Verde A, et al. The prevalence of acne in the north of Portugal. J Eur Acad Dermatol Venereol 2006;20(10):1287-95.

33. Tasoula E, Gregoriou S, Chalikias J, Lazarou D, Danopoulou I, Katsambas A, et al. The impact of acne vulgaris on quality of life and psychic health in young adolescents in Greece. Results of a population survey. An Bras Dermatol 2012;87(6):862-9. Available from https:// www.ncbi.nlm.nih.gov.

34. Bagatin E, Timpano DL, Guadanhim LR, Nogueira VM, Terzian LR, Steiner D, et al. Acne vulgaris: Prevalence and clinical forms in adolescents from São Paulo, Brazil. An Bras Dermatol 2014;89(3):428-35. Available from: https://www.ncbi.nlm.nih.gov.

35. Rademaker M, Garioch JJ, Simpson NB. Acne in schoolchildren: No longer a concern for dermatologists. BMJ 1989;298(6682):1217-9. Available from: https://www.ncbi.nlm.nih.gov/pubmed/2526674.

36. Maldonado RR, Tamayo SL, Velazquez E. Epidemiology of skin diseases in 10,000 patients of pediatric age. Bol Med Hosp Infant Mex 1977; 34:137-161

37. Smithard A, Glazebrook C, Williams HC. Acne prevalence, knowledge about acne and psychological morbidity in mid-adolescence: A community-based study. Br J Dermatol 2001;145(2):274-9. Available from: https://www.ncbi.nlm.nih.gov/pubmed/11531791.

38. Yeung CK, Teo LH, Xiang LH, Chan HH. A community-based epidemiological study of acne vulgaris in Hong Kong adolescents. Acta Derm Venereol 2002;82(2):104-7. Available from: https://www.ncbi. nlm.nih.gov/pubmed/12125936.

39. Purvis D, Robinson E, Watson P. Acne prevalence in secondary school students and their perceived difficulty in accessing acne treatment. N Z Med J 2004;117(1200):U1018. Available from: https://www.ncbi.nlm. nih.gov/pubmed/15475988.

40. Amado JM, Matos ME, Abreu AM, Loureiro L, Oliveira J, Verde $\mathrm{A}$, et al. The prevalence of acne in the north of Portugal. J Eur Acad Dermatol Venereol 2006;20(10):1287-95.

41. Tan HH, Tan AW, Barkham T, Yan XY, Zhu M. Community-based study of acne vulgaris in adolescents in Singapore. Br J Dermatol 2007;157(3):547-51. Available from: https://www.ncbi.nlm.nih.gov/ pubmed/17655737.

42. Nijsten T, Rombouts S, Lambert J. Acne is prevalent but use of its treatments is infrequent among adolescents from the general population. J Eur Acad Dermatol Venereol 2007;21(2):163-8.

43. Uslu G, Sendur N, Uslu M, Savk E, Karaman G, Eskin M. Acne: Prevalence, perceptions and effects on psychological health among adolescents in Aydin, Turkey. J Eur Acad Dermatol Venereol. 2008;22(4):462-9. Available from: https://www.ncbi.nlm.nih.gov/ pubmed/18179519.

44. Husain Y. Acne vulgaris in Nigerian adolescents' prevalence, severity, beliefs, perceptions, and practices. Int $\mathrm{J}$ Dermatol 2009;48:498-505

45. Ismail NH, Manaf ZA, Azizan NZ. High glycemic load diet, milk and ice cream consumption are related to acne vulgaris in Malaysian young adults: A case control study. BMC Dermatol 2012;12:13. Availabl from: https://www.ncbi.nlm.nih.gov/pubmed/22898209.

46. Stathakis V, Kilkenny M, Marks R. Descriptive epidemiology of acne vulgaris in the community. Australas J Dermatol 1997;38(3):11523. Availablke from: onlinelibrary.wiley.com/doi/10.1111/j.14400960.1997...x/abstract.

47. Suh DH, Shin JW, Min SU, Lee DH, Yoon MY, Kim NI, et al. Treatment-seeking behaviors and related epidemiological features in Korean acne patients. J Korean Med Sci 2008;23(6):969-74

48. Krowchuk DP. Managing acne in adolescents. Pediatr Clin North Am 2000;47(4):841-57.

49. Tallab TM. Beliefs, perceptions and psychological impact of acne vulgaris among patients in the Assir region of Saudi Arabia. West Afr J Med 2004;23(1):85-7. Available from: https:/www.ncbi.nlm.nih.gov/ pubmed/15171537

50. Lucky AW, Biro FM, Simbartl LA, Morrison JA, Sorg NW. Predictors of severity of acne vulgaris in young adolescent girls: Results of a fiveyear longitudinal study. J Pediatr 1997;130(1):30-9.

51. Granstein RD. Ultraviolet radiation effects on immunologic function. Reg Immunol 1990;3(2):112-9.

52. Middleton JD, Allen BM. The influence of temperature and humidity on stratum corneum and its relation to skin chapping. J Soc Cosmet Chem 1973;24:239-43

53. Diffey BL, Larkö O. Clinical climatology. Photodermatol 1984;1(1):30-7.

54. Plowing G, Kligman AM. Acne. Morphogenesis and Treatment. Berlin: Springer; 1975. p. 295-6.

55. Sardana K, Sharma RC, Sarkar R. Seasonal variation in acne vulgaris Myth or reality. J Dermatol 2002;29(8):484-8. Available from: https:// www.ncbi.nlm.nih.gov/pubmed/12227481.

56. Anderson PC. Foods as the cause of acne. Am Fam Physician 1971;3(3):102-3. Available from: https://www.ncbi.nlm.nih.gov/ pubmed/4251510.

57. Danby FW. Nutrition and acne. Clin Dermatol 2010;28(6):598-604. Available from: https://www.ncbi.nlm.nih.gov/pubmed/21034984.

58. Smith RN, Mann NJ, Braue A, Mäkeläinen H, Varigos GA. The effect of a high-protein, low glycemic-load diet versus a conventional, high glycemic-load diet on biochemical parameters associated with acne vulgaris: A randomized, investigator-masked, controlled trial. J Am Acad Dermatol 2007;57(2):247-56. Available from: https://www.ncbi. nlm.nih.gov/pubmed/17448569.

59. Sunay D, Baykir M, Ates G, Eksioglu M. Alexithymia and acne vulgaris: A case control study. Psychiatry Investig 2011;8(4):327-33. Available from: https://www.ncbi.nlm.nih.gov.

60. Lee KW, Kim YJ, Lee HJ, Lee CY. Cocoa has more phenolic phytochemicals and a higher antioxidant capacity than teas and red 
wine. J Agric Food Chem 2003;51(25):7292-5. Available from: https:/ www.ncbi.nlm.nih.gov/pubmed/14640573

61. Pietta PG. Flavonoids as antioxidants. J Nat Prod 2000;63:1035-42. Available from: pubs.acs.org/doi/abs/10.1021/np9904509.

62. Natalya T. The influence of dietary habits on acne. World J Med Sci 2013;8(3):212-6. Available from:

https://www.idosi.org/wjms/8(3)13/8.pdf. Available from:

63. Rtajpss analysis and antimicrobial efficacy of potential herbs against selected microbes. Asian J Pharm Clin Res 2015;8(2):232-7. Available from: http://innovareacademics.in/journals/index.php/ajpcr/article/ view/4036/2166.

64. BalijepalliMK, BuruAS, Sakirolla R,PichikaMR.Cinnamomumgenus:A review on its biological activities. 2016;9(2):1-11. Available from:ttp://www.innovareacademics.in/journals/index.php /ijpps/article/view/11156/9561 